\title{
HONY. SECRETARY GENERAL'S DESK
}

\section{Dear Friends,}

You may have noticed that over the last few years the activities of your Institute has been increased considerably. The ANB operation have grown and along with it the ANBCC operations have commenced over the last two years. This has necessitated moving these divisions to a hired premises in Fern Road. The MES assessment activities are expanding rapidly and recent initiatives in the Skill Development area and focus on NWTCS activities will also require more space. Due to this growth in activities it was felt necessary to acquire bigger accommodation to provide adequate space to accommodate all our activities. As per decision of Central Council, Building Committee under the Chairmanship of Mr B. K. Misra, finalized a suitable building for the proposed IIW-India House, situated at 200, Kalikapur Road, Kolkata - 99 adjacent to connector of EM by pass, Kolkata. The final purchase deed was registered by the Registrar of Assurance on the auspicious day 23rd May، 2013. We are hopeful to Inaugurate the IIW-India House during AGM. I appeal to all members of the Institute to generously donate money to the Building Fund to enable us to complete the Office renovation.

Coming back to activities of the Institute, IIW-India has made remarkable progress in the Skill Development area. Following our collaboration agreement with IL \& FS our NWTCS programme is being aligned to meet the industry requirement. To this end IIW-India is in process of signing an MOU with Automobile Sector Skill Council where IIWIndia will be a knowledge partner for sourcing of welders through our ATI's and other welding training institute of ASDC. We are also in close touch with FICCI \& PMMAI to associate us as a knowledge partner for sector Skill Council for capital goods IIW-India is also closely coordinating with Sector Skill Council for Steel Sector which is under formation.

As planned the first welding instructors training program was very successfully conducted in collaboration with NITTR (A unit of Central Govt. Ministry of HRD), Kolkata from 8th -27th April, 2013. The second is being conducted from 12-31st August, 2013. Further, to upgrade our website to International Standards as well as make it user friendly we have taken an urgent development programme.

To introduce uniformity of our Branch Accounts we have introduced Internal Audit System nationally and accordingly an Audit team visited most of the Branches, which yielded a good response, as a result by now we have received audited accounts from all our Branches.

It has been decided in the last Council that the 47th Annual General Meeting of your Institute will be held on Saturday, the 28th September, 2013 at Kolkata. All members are requested to make it convenient to attend the AGM.

This year the National Weld Meet (NWM-2013) will be held on Saturday, the 31st August, 2013 at Hotel Surya Palace, Baroda, hosted by our Baroda Branch on the theme, "Challenges on Dissimilar Welding". Members are requested to attend this meet. Necessary details have already been given in this issue. Our Mega event International Congress of International Institute of Welding will be held at Pragati Maidan, New Delhi from 9th to 11th April 2014 with Concurrent Event : International Exhibition Weld India 2014 in Association with FABTECH / AWS from 10th to 12 th April.

Let us work together to take this Institute to a greater heights.

With warm regards.

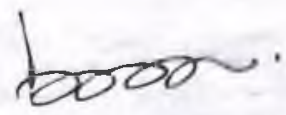

\section{Parimal Biswas}

M.No +919831052652

E-Mail Id : parimal.biswas@iiwindia.com 